\title{
Nitrite tolerance of different ectomycorrhizal and wood- and litter-decomposing fungi
}

\author{
VEIKKO HINTIKKA and KAROLIINA NIEMI
}

\begin{abstract}
HINTIKKA, V. \& NIEMI, K. 1999: Nitrite tolerance of different ectomycorrhizal and wood- and litter-decomposing fungi. - Karstenia 39: 43-48. Helsinki. ISSN 04353402

The effect of nitrite $\left(\mathrm{NO}_{2}{ }^{-}\right)$on the in vitro radial growth of 10 ectomycorrhizal and 11 wood- and 19 litter-decomposing fungi was studied by cultivating mycelia on malt extract (ME) agar supplemented with different amounts of $\mathrm{NaNO}_{2}$. Nitrite tolerance differed very much between fungus species. Piptoporus betulinus and Collybia butyracea were the only fungi, which were not able to grow on $\mathrm{NO}_{2}$-media, while a mycorrhizal fungus Cenococcum geophilum as well as a litter-decomposing fungus Coprinus cinereus grew even at $2500 \mathrm{mg} \mathrm{l}^{-1} \mathrm{NaNO}_{2}$. Generally, the litter-decomposing fungi thriving in gardens, dung and other nitrogen $(\mathrm{N})$ rich places were the most $\mathrm{NO}_{2}$ tolerant species which shows that they have adapted to continuous high supply of nitrogen. The possible mechanisms involving in $\mathrm{NO}_{2}$-tolerance are discussed.
\end{abstract}

Key words: Nitrite $\left(\mathrm{NO}_{2}-\right)$, tolerance, ectomycorrhizal fungi, wood and litter decomposing fungi.

Veikko Hintikka \& Karoliina Niemi $*$, Department of Plant Biology / Botany, P.O. Box 27, FIN-00014 University of Helsinki, Finland. * Permanent address: Department of Ecology and Environmental Science, University of Kuopio, P.O. BOX 1627, FIN-7021I Kuopio, Finland

\section{Introduction}

Nitrite $\left(\mathrm{NO}_{2}^{-}\right)$is an intermediate product in the conversion of ammonium $\left(\mathrm{NH}_{4}+\right)$ to nitrate $\left(\mathrm{NO}_{3}-\right)$, of $\mathrm{NO}_{3}$ - to nitrogen gas $\left(\mathrm{N}_{2}{ }^{4}\right)$ in soils and of $\mathrm{NO}_{3}$ - to $\mathrm{NH}_{4}+$ in plants and fungi. Owing to faster oxidation of $\mathrm{NO}_{2}$ - to $\mathrm{NO}_{3}$ - than of $\mathrm{NH}_{4}$ + to $\mathrm{NO}_{2}-$, accumulation of $\mathrm{NO}_{2}$ - is limited in soil, and its concentration does not normally exceed $1 \mathrm{mg}$ $\mathrm{g}^{-1}$ soil (Haynes and Sherlock 1986). Concentration of $\mathrm{NO}_{2}$ - may, however, dramatically increase as a result of fertilization with urea (Löffler et al. 1986, Monaghan \& Barrachloug 1992) or inorganic N (Jones \& Schwab 1993, Burns et al. 1995) or of industrial $\mathrm{N}$ deposition as well. According to Bingham et al. (1954) concentration of $\mathrm{NO}_{2}^{-}$ above $50 \mu \mathrm{g} \mathrm{g}^{-1}$ in the root zone produces toxicity symptoms. In acidic conditions, such as in Nordic forest soils, toxic level can be reached already at much lower concentration due to forma- tion of uncharged nitrous acid (Lee 1979, Zsolbas et al. 1993).

Reduction to $\mathrm{NH}_{4}+$ and further incorporation to organic form is a prerequisite for utilization of $\mathrm{NO}_{2}$ - in organisms. Reduction of $\mathrm{NO}_{2}$ - to $\mathrm{NH}_{4}+$ is catalyzed by nitrite reductase enzyme (NiR) which has been found both in chlorophyllous and non-chlorophyllous parts of plants (e.g. Duncanson et al. 1992, Wray 1993, Seith et al 1994). Reduction of $\mathrm{NO}_{2}$ - in fungi has not been investigated as widely as in plants, and the studies have mainly concentrated on lower fungi, such as Neurospora crassa (Lafferty et al. 1974, Greenbaum et al. 1978, Exley et al. 1993) and Candida nitratophila (Al Kubisi et al. 1996). Reduction of $\mathrm{NO}_{2}$ - has also been observed in some wood-decomposing fungi (Gundersen 1967) as well as in an ectomycorrhizal fungus Hebeloma 
cylindrosporum (Plassard et al. 1984). As high concentrations $\mathrm{NO}_{2}$ - is known to be toxic to fungi (Löffler et al. 1986), and therefore it has been used to inhibit infection of, for example, Heterobasiodion annosum in tree stumps (Gundersen 1967, Schönhar 1997).

Table 1. Fungal species used in the study.

Species

Mycorrhizal fungi

Amanita muscaria (L. : Fr.) Hook. Amanita rubescens (Pers. : Fr.) S.F. Gray Cenococcum geophilum (Sow.) Ferd. \& Winge Hebeloma sp.

Leccinum scabrum (Bull. : Fr.) S.F. Gray

Paxillus involutus (Batsch. : Fr.) Fr.

Suillus granulatus (L. : Fr.) Roussel

Suillus luteus (L. : Fr.) Roussel

Suillus variegatus (Sw. : Fr.) O. Kuntze

Tricholoma album (Fr.) Kumm.

Wood-decomposing fungi

Fomitopsis pinicola (Sw. : Fr.) P. Karst.

Hypholoma fasciculare (Huds. : Fr.) Kumm.

Hypholoma lateritium (Scaeff. : Fr.) Schroet.

Ischnoderma benzoinum (Wahlenb. : Fr.) P. Karst.

Kuehneromyces mutabilis (Schaeff. : Fr.) Sing. \& Smith

Lentinus edodes (Berk.) Sing.

Lentinus lepideus (Fr. : Fr.) Fr.

Piptoporus betulinus (Bull. : Fr.) P. Karst.

Pleurotus pulmonarius (Fr.) Quel.

Stereum sanguinolentum (Alb. \& Schw.) Fr.

Trametes versicolor (L. : Fr.) Pilát

Litter-decomposing fungi

Agrocybe molesta (Lasch) Sing.

Coprinus bisporus Lange

Coprinus cinereus (Schaeff. : Fr.) S.F. Gray

Coprinus disseminatus (Pers. : Fr.) S.F. Gray

Coprinus heptemerus M. Lange \& A.H. Smith

Coprinus micaceus A (Bull. : Fr.) Fr.

Coprinus micaceus B (Bull. : Fr.) Fr.

Coprinus tuberosus Quel.

Cyathus striatus (Hudson : Pers.) Willd.

Collybia butyracea (Bull. : Fr.) Kumm.

Leucoagaricus cretaceus (Bull. : Fr.) Moser

Marasmius androsaceus (L. : Fr.) Fr

Marasmius bulliardii Quel.

Marasmius scorodonius (Fr. : Fr.) Fr.

Mycena galopus (Pers. : Fr.) Kumm.

Mycena vulgaris (Pers. : Fr.) Kumm.

Mycena vitilis (Fr.) Quel.

Micromphale perforans (Fr.) Sing.

Tephrocybe tylicolor (Fr.) Moser
In order to obtain more information about $\mathrm{NO}_{2}$ - tolerance among higher fungi, we investigated the ability of both ectomycorrhizal and wood- and litter-decomposing fungi to grow in vitro on the media with different concentrations of $\mathrm{NO}_{2}-$.

\section{Materials and methods}

\section{Fungal material}

All the fungi of the present study were from the culture collection of Department of Plant Biology in University of Helsinki (Table 1). The fungi, except the genus Coprinus, have been isolated from surroundings of Helsinki by Dr. Veikko Hintikka. The Coprinus species have been isolated by Mr. Paavo Höijer, Porvoo. The fungi were cultivated on $1 \%$ malt extract (ME) Difco or Melin Norkrans (MMN) (Marx 1969) agar slants at ca. $+5^{\circ} \mathrm{C}$ and were transferred to fresh media about twice a year.

\section{Experimental design}

The fungi were cultivated in Petri dishes containing $1 \% \mathrm{ME}$ (Difco), $1 \%$ agar (Bacteriologique type A) and different amounts of $\mathrm{NaNO}_{2}$ (Table 2).

Table 2. $\mathrm{NaNO}_{2}$ concentrations and $\mathrm{pH}\left(\mathrm{H}_{2} \mathrm{O}\right)$ of the media at the beginning of the experiment.

\begin{tabular}{cl}
\hline $\mathrm{NaNO}_{2}$ concentration $\left(\mathrm{mg} \mathrm{l}^{-1}\right)$ & $\mathrm{pH}$ \\
\hline 0 & 5.81 \\
25 & 5.90 \\
50 & 5.60 \\
100 & 6.12 \\
250 & 6.16 \\
500 & 6.28 \\
750 & 6.31 \\
1000 & 6.32 \\
2500 & 6.40 \\
\hline
\end{tabular}

Filter-sterilized (Millipore, pore size $0.2 \mu \mathrm{m}$ ) $\mathrm{NaNO}_{2}$ was added to $\mathrm{ME}$ agar after autoclaving. The $\mathrm{pH}\left(\mathrm{H}_{2} \mathrm{O}\right)$ of the media was determined before cultivation. It increased from $\mathrm{pH} 5.6$ (50 $\left.\mathrm{mg} \mathrm{l}^{-1}\right) \mathrm{NaNO}_{2}$ to 6.4 (2500 $\mathrm{mg} \mathrm{l}^{-1} \mathrm{NaNO}_{2}$, Table 2). 
For the experiment, a mycelial plug, about $5 \mathrm{~mm}$ in diameter, was transferred to fresh medium and cultivated in the dark at $21^{\circ} \mathrm{C}$. The radial growth $(\mathrm{mm})$ of the fungi was measured after the growing period of 2 (litter and wood decomposing fungi), 4 (ectomycorrhizal fungi, except Suillus spp.) or 7 (Suillus species) weeks.

\section{Results}

Responses to $\mathrm{NaNO}_{2}$ differed remarkably between fungus species (Table 3). Although all ectomycorrhizal fungi were able to grow on the $\mathrm{NO}_{2}$ - media, as a group they were more sensitive to $\mathrm{NO}_{2}$ - than the wood- and litter-decomposing fungi. Within mycorrhizal fungi, Amanita species were the most sensitive. The growth of $A$. rubescens was almost completely inhibited even at the lowest $\mathrm{NaNO}_{2}$ concentration ( $25 \mathrm{mg} \mathrm{l}^{-1} \mathrm{NaNO}_{2}$ ) and that of $A$. muscaria at $50 \mathrm{mg} \mathrm{l}^{-1} \mathrm{NaNO}_{2}$.
Cenococcum geophilum was the exception among mycorrhizal fungi by growing at the highest concentration of $\mathrm{NaNO}_{2}\left(2500 \mathrm{mg} \mathrm{l}^{-1}\right)$.

Wood-decomposing fungi formed a heterogenous group in $\mathrm{NO}_{2}$ - tolerance. Piptoporus betulinus was the only fungus, which was not able to grow on $\mathrm{NO}_{2}$ - media (Table 3). Because it grew quite well on the control medium (no added $\mathrm{NaNO}_{2}$ ), mycelium was viable. Hypholoma fasciculare and Trametes versicolor were the most tolerant species by growing at $750 \mathrm{mg} \mathrm{l}^{-1} \mathrm{NaNO}_{2}$. Host plant of the decomposing fungus had no correlation with $\mathrm{NO}_{2}$ - tolerance of the species.

Generally, the litter-decomposing fungi growing in gardens, roadsides, dung and other $\mathrm{N}$ rich places tolerated $\mathrm{NO}_{2}$ - best. For example, all the Coprinus species were able to grow at $250 \mathrm{mg} \mathrm{l}^{-1}$ or at higher concentration of $\mathrm{NaNO}_{2}$. Coprinus cinereus would have tolerated even higher concentration than $2500 \mathrm{mg} \mathrm{l}^{-1}$, because on this medi-

Table 3. Ability of different ectomycorrhizal and wood and litter-decomposing fungi to grow on $\mathrm{NaNO}_{2}$ agar media. The highest concentration $\left(\mathrm{g}^{1^{-1}}\right)$, at which growth was still recorded.

\begin{tabular}{|c|c|c|c|}
\hline $\begin{array}{l}\mathrm{NaNO}_{2}^{-} \\
\text {concentration }\end{array}$ & $\begin{array}{l}\text { Ectomycorrhizal } \\
\text { fungi }^{1}\end{array}$ & $\begin{array}{l}\text { Wood-decomposing } \\
\text { fungi }{ }^{2}\end{array}$ & $\begin{array}{l}\text { Litter-decomposing } \\
\text { fungi }{ }^{2}\end{array}$ \\
\hline 0 & & Piptoborus betulinus & Collybia butyracea \\
\hline 25 & Amanita rubescens & & Marasmius androsaceus \\
\hline \multirow[t]{4}{*}{50} & Amanita muscaria & Lentinus lepideus & Micronphale perforans \\
\hline & Paxillus involutus & & Mycena vitilis \\
\hline & Suillus variegatus & & Mycena calopus \\
\hline & Suillus granulatus & & \\
\hline \multirow[t]{3}{*}{100} & Leccinum scabrum & Ischnoderma benzoinum & Mycena vulgaris \\
\hline & Suillus luteus & Kuehneromyces mutabilis & \\
\hline & Tricholoma album & Lentinus edodes & \\
\hline \multirow[t]{6}{*}{250} & Hebeloma sp. & Hypholoma lateritium & Coprinus heptemerus \\
\hline & & Stereum sanguinolentum & Coprinus micaceus A \\
\hline & & & Coprinus tuberosus \\
\hline & & & Cyanthus striatus \\
\hline & & & Marasmius bulliardii \\
\hline & & & Marasmius scorodonius \\
\hline \multirow[t]{2}{*}{500} & & Pleurotus pulmonarius & Coprinus micaceus $\mathrm{B}$ \\
\hline & & Fomitopsis pinicola & Tephrocybe tylicolor \\
\hline \multirow[t]{3}{*}{750} & & Hypholoma fasciculare & Agrocybe molesta \\
\hline & & Trametes versicolor & Coprinus bisporus \\
\hline & & & Coprinus disseminatus \\
\hline 1000 & & & Leucoagaricus cretaceus \\
\hline 2500 & Cenococcum geophilum & & Coprinus cinereus \\
\hline
\end{tabular}

14 weeks, except Suillus species 7 weeks, after inoculation.

22 weeks after inoculation. 
um mycelium covered half of the Petri dish. Fungi decomposing needle litter were sensitive to $\mathrm{NO}_{2}-;$ Collybia butyracea was not able to grow on $\mathrm{NO}_{2}$ - media at all.

\section{Discussion}

Although $\mathrm{NO}_{2}$ - plays an important role in $\mathrm{N}$ metabolism in both plants and fungi, as high concentrations it is a ion of possible toxicity. It can inhibit the uptake of some important cations (Zolbos et. al. 1993) and destroy both DNA and RNA by deaminating purine rings. Inhibitory effects of $\mathrm{NO}_{2}$ - are also related to its similarity to a sulphite ion (Pateman \& Kinghorn 1976).

Ability to tolerate inorganic $\mathrm{N}, \mathrm{NO}_{2}$ - included, varies greatly between fungus species. This has been observed as changes in fungal population in areas polluted by $\mathrm{N}$ originating from industry and agriculture (e.g. Ohenoja 1978, Brandrud 1995, Holopainen et. al 1996). In the study of Holopainen et al. (1996), ectomycorrhizal Suillusand Piloderma-species sensitive to $\mathrm{NO}_{3}$ - and $\mathrm{NH}_{4}+$ were replaced by more tolerant species Cenococcum geophilum and Paxillus involutus in the soil near a pulp mill in eastern Finland. In the case of Suillus species and Cenococcum geophilum, our results in vitro are in agreement with those obtained by Holopainen et al. (1996). In the present study, the Paxillus involutus strain was, however, as sensitive to $\mathrm{NO}_{2}-$ as Suillus species. Arnebrant (1994) observed great difference in $\mathrm{N}$ tolerance between two Paxillus involutus strains which shows that in addition to variation between different species, ability to use and tolerate $\mathrm{N}$ may vary remarkably within species. Therefore, it is difficult to make generalizations for species.

Because concentration of $\mathrm{N}$ in wood is low, wood-decomposing fungi would be expected to be sensitive to $\mathrm{NO}_{2}-$. However, Gundersen (1967) found $\mathrm{NO}_{2}$ - tolerant species and strains by cultivating mycelia on sterilized pine stem disk. In his study, all the fungi tested were able to grow even at $\mathrm{NaNO}_{2}$ concentration of $1000 \mathrm{mg} \mathrm{l}^{-1}$, although the growth of, for example, Heterobasidion annosum, Fomitopsis pinicola and three Polyporus species was reduced significantly. The growth of Stereum sanguinolentum was still the same as on the control medium. Wood-decomposing fungi were, however, 10-20 times more sensitive to $\mathrm{NO}_{2}$ - than microfungi, such as some Penicillium and Trichoderma species. In the present study, Fomitopsis pinicola tolerated $\mathrm{NO}_{2}$ - better than Stereum sanguinolentum, but it was not able to grow at as high $\mathrm{NO}_{2}$ - concentration as reported by Gundersen (1967).

The concentration of $\mathrm{N}$ in deciduous leaves is usually higher than that in needles of conifers (Berg \& Cortina 1995). Therefore, the decomposing fungi of deciduous leaves might tolerate higher $\mathrm{N}$ concentration than fungi decaying needles. In our in vitro study of $\mathrm{NO}_{2}$ - tolerance, this tendency was observed. The most tolerant fungi were, however, the species decomposing litter in gardens, dumps and roadsides rich in N. For example, the growth of most Coprinus species occurring in $\mathrm{NH}_{4}+$ - and urea-rich conditions in nature, where accumulation of $\mathrm{NO}_{2}$ - is obvious, was inhibited only at very high concentrations of $\mathrm{NaNO}_{2}$.

Although synthesis and regulation of NiR enzyme is important in adaptation to high concentrations of $\mathrm{NO}_{2}^{-}$, tolerance to $\mathrm{NO}_{2}$ - in fungi depends on several mechanisms. Some plants have been observed to oxidize $\mathrm{NO}_{2}$ - to $\mathrm{NO}_{3}$ - and in this way avoid accumulation of $\mathrm{NO}_{2}$ - (Funkhouser et al. 1981, Aslam et al. 1989). In addition, $\mathrm{NO}_{3}$ - is the ion inducing NiR enzyme (Aslam et al. 1989; Wray 1993). Fungi might have the same kind of system first to induce oxidation of $\mathrm{NO}_{2}$ - and then to increase activity of $\mathrm{NiR}$ with $\mathrm{NO}_{3}$ - formed. Nitrogen may be also stored and released gradually. Deposits rich in $\mathrm{N}$ have been found in vacuoles of ectomycorrhizal fungus Cenococcum geophilum after N-treatment (Kottke et al. 1995). Amino acids and proteins have been suggested to be predominant $\mathrm{N}$ forms in these deposits (Wallenda \& Kottke 1998), but they might also contain tiny amounts of inorganic N. On the other hand, Choudary (1993) has suggested that the yeasts tolerating high concentrations of inorganic $\mathrm{N}$ keep the ion in a transient state until they are able to change it to a less toxic form.

Plassard et al. (1984) showed that nitrite in medium induced NiR activity in the mycelium of Hebeloma cylindrosporum. Induction depended, however, on $\mathrm{pH}$ of the media. Acidity has an important effect on both growth and $\mathrm{N}$ metabolism in fungi: acidic conditions increase toxicity of $\mathrm{NO}_{2}$ - (Gundersen 1967, Plassard et al. 1984, Chang \& Chung 1988). The decrease of $\mathrm{pH}$ from 6 to 4 seems to be most critical. In our study, 
$\mathrm{NaNO}_{2}$ increased $\mathrm{pH}$ of the agar media which might compensate some toxic effects of $\mathrm{NO}_{2}$-. On the other hand, before toxic concentrations of $\mathrm{NO}_{2}-$, too high $\mathrm{pH}$ (over 6) might inhibit the growth of some ectomycorrhizal fungi originally isolated from acid soil.

Nitrous acid, formed from $\mathrm{NO}_{2}$ - in acid conditions, is known to react with phenolic compounds. This reaction has been suggested as a possible mechanism for gaseous $\mathrm{N}$ loss from acid soil (Christianson et al. 1979, Smith \& Chalk 1980). The amount of phenolic compounds, especially tannins, have been shown to increase in plants after different stress conditions (Briggs 1991, Holopainen et al. 1996), but the importance of them during $\mathrm{N}$ stress is still unclear. The formation of phenols could be some kind of safety measure to prevent toxic effects of nitrous acid or $\mathrm{NO}_{2}$-. The possibility that phenolic compounds could prevent $\mathrm{N}$ accumulation in cells should be investigated.

Our study shows that although in vitro conditions simplify responses, relationship between $\mathrm{N}$ concentration in the growth site of the fungus and $\mathrm{NO}_{2}$ - tolerance in vitro can be found. Because only one strain of a species was tested and because variation within species is known to be great, generalization of tolerance is, however, difficult. Therefore, it would be important to test more strains originating from different areas.

\section{References}

Al Kubisi, A., Ali, A.H. \& Hipkin, C.R. 1996: Nitrite assimilation by the yeast Candida nitratophila. - New Phytol. 132: 313-316.

Arnebrant, K. 1994: Nitrogen amendments reduce the growth of extramatrical ectomycorrhizal mycelium. - Mycorrhiza 5: 7-15.

Aslam, M. \& Huffaker, R.C. 1989: Role of nitrate and nitrite in the induction of nitrite reductase in leaves of barley seedlings. - Plant Physiol. 91: 1152-1156.

Berg, B. \& Cortina, J. 1995: Nutrient dynamics in some decomposing leaf and needle litter types in Pinus sylvestris forest. - Scand. J. For. Res. 10: 1-11.

Bingham, F.T., Chapman, H.D. \& Pugh, A.L. 1954: Solution-culture studies of nitrite toxicity to plants. Soil Sci. Soc. Am. Proc. 18: 305-308.

Bowsher, C.G., Hucklesby, D.P. \& Emes, M.J. 1989: Nitrite reduction and carbohydrate metabolism in plastids purified from roots of Pisum sativum L. - Planta 177: 359-366.

Brandrud, T.E. 1995. The effects of experimental nitrogen addition on the ectomycorrhizal fungus flora in an oligotrophic spruce forest at Gårdsjön, Sweden. For. Ecol. Manag. 71: 111-122.

Briggs, M.A. 1991: Influence of herbivory and nutrient availability on biomass, reproduction and chemical defences of Lotus corniculatus L. - Func. Ecol. 5: 780-786.

Burns, L.C., Stevens, R.J., Smith, R.V. \& Cooper, J.E. 1995: The occurrence and possible sources of nitrite in a grazed, fertilized, grassland soils. - Soil Biol. Biochem. 27: 47-59.

Chang, T.H. \& Chung, B.K. 1988: Effects of ammonium, nitrite and calsium compounds on the germination and mycelial growth of Phytophtora capsici causing red pepper fruit rot. - Kor. J. Mycol. 16: 1-8.

Choudary, P.V. 1993: Ability to assimilate nitrogenous oxides is limited to a few species of yeasts. - Microbios 74: 241-248.

Christianson, C.B., Hedlin, R.A. \& Cho, C.M. 1979: Lost of nitrogen from soil during nitrification of urea. - Can. J. Soil Sci. 59: 147-154.

Duncanson, E., Ip.,S.-M., Sherman, A., Dennis, W.K. \& Wray, J. 1992: Synthesis of nitrite reductase in regulated differently in leaf and root of barley (Hordeum vulgare L.) - Plant Science 87: 151-160.

Exley, G.E., Colandene, J.D. \& Garret, R.H. 1993: Molecular cloning, characterization and nucleotide sequence of nit-6, the structural gene for nitrite reductase in Neurospora crassa. - J. Bacteriol. 175: 23792393.

Friemann, A., Lange, M., Hachtel, W. \& Brinkmann, K. 1992: Induction of nitrate assimilatory enzymes in the tree Betula pendula. - Plant Physiol. 99: 837842 .

Greenbaum, P., Prodouz, K.N. \& Garret, R.H. 1978: Preparation and some properties of homogenous Neurospora crassa assimilatory $\mathrm{NADPH}$-nitrite reductase. - Biochemica et Biophysica Acta 526: 5264.

Gundersen, K. 1967: Nitrite as a nutrient for microfungi of the outer stem cortex of pine and spruce and its toxicity to Fomes annosus. - Stud. For. Suec. 43: 119.

Haynes, R.J. \& Sherlock, R.R. 1986: Gaseous loses of nitrogen. - In: Haynes, R.J. (ed.), Mineral nitrogen in the plant soil system: 242-302. Academic Press, Orlando.

Holopainen, T., Heinonen-Tanski, H. \& Halonen, A.: 1996: Injuries to Scots pine mycorrhizas and chemical gradients in forest soil in the environment of a pulp mill in central Finland. - Water Air Soil Pollut. 87: $111-130$.

Jones, R.D. \& Schwab, A.P. 1993: Nitrate leaching and nitrite occurrence in a fine-textured soil. - Soil Science 155: 272-282.

Kottke, I., Holopainen, T., Alanen, E. \& Turnau, K. 1995: Deposition of nitrogen in vacuolar bodies of Cenococcum geophilum Fr. mycorrhizas as detected by electron loss spectroscopy. - New Phytol. 129: 411-416.

Lafferty, M.A. \& Garret, R.H. 1974: Purification and properties of the Neurospora crassa assimilatory nitrite reductase. - J. Biol. Chemistry 249: 7555-7567.

Lee, R.B. 1979. The effect of nitrite on root growth of barley and maize. - New Phytol. 83: 615-622. 
Löffler, H.J.M., Cohen, E.B., Oolbekkink, G.T. \& Schippers, B. 1986: Nitrite as a factor in the decline of Fusarium oxysporum f.sp. dianthi in soil supplemented with urea or ammonium chloride. - Neth. J. Pl. Path. 92: 153-162.

Marx, D.H. 1969: The influence of ectotrophic mycorrhizal fungi on the resistance of pine roots to pathogenic infection I. Antagonism of mycorrhizal fungi to root pathogenic fungi and soil bacteria. - Phytopathol. 56: 153-163.

Monagham, R.M. \& Barraclough, D. 1992: Some chemical and physical factors affecting the rate and dynamics of nitrification in urine-affected soil. - Plant \& Soil 143: 11-18.

Ohenoja, E. 1978. Mushrooms and mushroom yields in fertilized forests. - Ann. Bot. Fenn. 15: 38-46.

Pateman, J.A. \& Kinghorn, J.R. 1976: Nitrogen metabolism. - In: Smith, J.E. and Berry, D.R. (eds.), The filamentous fungi 2: 159-237. New York. Wiley.

Plassard, C., Mousain, D. \& Salsac, L. 1984. Mesure in vivo et in vitro de l'activite nitrite reductase dans less thalles de Hebeloma cylindrosporum, champignon basidiomycete. - Physiol. Veg. 22: 147-154.
Schönhar, S. 1997: Heterobasidion annosum in Norway spruce stands on base-rich soils in SW-Germany - results of 30 years research. - Allgem. Forst- und Jagdzeitung 168: 26-30.

Seith, B., Setzer, B., Flaig, H. \& Mohr, H. 1994: Appearance of nitrate reductase, nitrite reductase and glutamine synthetase in different organs of the Scots pine (Pinus sylvestris L.) seedling as affected by light, nitrate and ammonium. - Physiol. Plant. 91: 419426.

Smith, C.J. \& Chalk, P.M. 1980: Fixation and loss of nitrogen during transformations of nitrite in soils. Soil. Sci. Soc. Am. J. 44: 288-291.

Wallenda, T. \& Kottke, I. 1998. Nitrogen deposition and ectomycorrhizas. - New Phytol. 139: 169-187.

Wray, J.L. 1993: Molecular biology, genetics and regulation of nitrite reduction in higher plants. - Physiol. Plant. 89: 607-612.

Zolbos, F., Haunold, E. Agnes, V. \& Herger, P. 1993: Nitrite in the root zone and its effects on ion uptake and growth of wheat seedlings. - Physiol. Plant. 89: 626-631.

Received on 8 June 1999 